\title{
THE IMPACT OF SELECTED REGULATIONS ON THE DEVELOPMENT OF PAYMENTS SYSTEMS IN POLAND
}

World trends indicate an increasing share of non-cash transactions in general transactions made by the nonfinancial sector. The promotion of non-cash transactions leads to the occurrence of various types of risks in banking operations. Modern technologies and household preferences, as well as the promotion of non-cash transactions, support the dynamic development of payment systems around the world. Non-financial sector is increasingly interested in new payment methods. According to the research, the global distribution of non-cash payments will be largely dominated by the e-wallet as well as debit and credit cards. The situation In Poland is different comparing to global trend. Bank transfers have a very large share in making non-cash payments. Despite we state that further marginalizing of trends leads to situation when profits in retail banking, mainly in the area of payments, is endangered. Data on retail payment systems supervised by the President of the National Bank of Poland confirm this trend. The preferred strategy for most banks is to create start-up programs (so-called incubators), to cooperate with companies from the FinTech sector, and to create venture funds to finance FinTech companies. Payment systems create a system composed of many complementary factors. Several types of risks related to the proper functioning of this financial market element are noticeable in these systems. According to the law, the National Polish Bank was entrusted with organizing monetary settlements and acting for the stability of the domestic financial system. System supervision is exercised over the payment system, which focuses on the functioning of payment systems, payment schemes, settlement systems and securities settlement systems, as well as providing acquiring services. Market regulators are facing a growing challenge regarding the level of regulation and availability of payment systems for non-bank payment organizations. Transformation of the supervision system is to be based on perception that development of systems and payment schemes is inevitable, the applicable regulations and the promotion of noncash transactions are conducive to the emergence of a larger number of enterprises that are not financial institutions, which can get access to household bank accounts.

Keywords: payments systems, mobile application, electronic wallet, banks.

Introduction. Changes in household preferences significantly determine the distribution channels of banking services. In addition, technology and market regulators support the development of modern distribution channels and payment systems - by promoting non-cash transactions. In recent years, new payment systems have been created in Poland, which, thanks to dynamically developing financial innovations, enable consumers to make cash settlements faster and cheaper. In the European Union as well as the national legal systems, there will be numerous changes in the payment market in the near future, enforced by, among others, implementation of the PSD II directive. In the field of payment services, companies from the FinTech sector play an important role, which through numerous regulations receive more and more powers - especially in the area of payments.

The infrastructure of the payment system in Poland. The financial market in the countries of Central and Eastern Europe is particularly open to modern solutions in the area of financial services development. Dynamic development and success of online and mobile banking, as well as the functionality of payment cards (including online payments using cards, BLIK system, proximity and contactless payments, cashback), leads to the interest of financial institutions in Central and Eastern Europe in innovative information technology solutions - especially in the field of payment systems. Nevertheless, 
the innovative technologies sector has not been created in recent years. The beginnings of development of the FinTech sector are dated to the end of the 19th century (Table 1).

Table 1 - Classification of FinTech eras (Developed by author based on, Douglas W. Arner, Janos Barberis, Ross P. Buckley, Fintech and reg tech in a nutshell and the future in a sandbox, CFA Institute Research Foundation, p.4.)

\begin{tabular}{|c|c|c|c|c|}
\hline Range & 1886-1967 & 1968-2008 & \multicolumn{2}{|c|}{ 2009-Present } \\
\hline Era & FinTech 1.0 & Fintech 2.0 & Fintech 3.0 & Fintech 3.5 \\
\hline Geography & Developed world & Global & Developed world & Developing world \\
\hline Key players & Infrastructure & Banks & \multicolumn{2}{|c|}{ Startups } \\
\hline Shift origin & Globalization & Technology & $\begin{array}{l}2008 \text { Financia } \\
\text { crisis }\end{array}$ & Market reform \\
\hline
\end{tabular}

In the analysis of the banks behaviour on the market of technological innovations used in finance, it is worth noting that until the financial crisis of 2007-2009, banks were the key institution in the development of this market. After 2009 , this market was dominated by start-ups. These companies in the early stages of the FinTech 3.5 era development were not noticed by banks - or even often marginalized. Nevertheless, due to numerous market regulations, including PSD II directive, banks change their strategies and business models and are more and more willing to take over/cooperate with start-up companies. Additionally, it should be emphasized that the regulations of the financial market create the FinTech 3.5 era.

The development of the financial system infrastructure in the countries of Central Europe is conditioned by, among others relatively low hourly gross labour costs (in Poland, 8.4 euros - the EU average is 24.6 euros) [Dorfleitner, Hornuf, Schmitt, Weber, 2016]. This creates the opportunity to form significant competitive advantages in the developing financial market in Poland.

Banks in Poland are characterized by modern solutions compared to other European banking sectors. The technology in the area of sales/distribution of financial services is developing very well in the modern financial market. Therefore, "FinTech banks" or "FinTech in banks" are more and more often mentioned in Poland, and the most innovative banks treat themselves as part of the FinTech sector [FinTech in Poland, 2016]. What is more, the ECB has developed the terms of obtaining a license for the FinTech bank [EBC, 2017].

Nevertheless, the management staff in charge of the banking sector in Poland also sees a number of threats related to the development of this market. According to the research, $43 \%$ of the management team claims that FinTech companies pose a serious threat to the operation of banks [The World FinTech report, 2017]. A very large number of start-up companies offering FinTech solutions sell their solutions to banks. However, companies from the FinTech sector also omit the traditional customer base that banks have and offer their solutions directly to clients with the innovative solutions they have created. Such solutions are very often noticeable in the sector of companies offering credits /loans, payment services and financial management.

The preferred strategy for most banks is to create start-up programs (so-called incubators), to cooperate with companies from the FinTech sector, and to create venture funds to finance FinTech companies. According to estimates, from $10 \%$ to $40 \%$ of bank revenues, and from $20 \%$ to $60 \%$ of profits in retail banking - mainly in the area of payments is endangered, through the development of companies from the FinTech sector [Implications of Fintech, 2017].

Modern technologies and household preferences, as well as the promotion of non-cash transactions, support the dynamic development of payment systems around the world. Based on Wordpay 2017 research, we can confirm the thesis that the non-financial sector is increasingly interested in new payment methods. According to the research of this organization, the global distribution of non-cash payments will 
be largely dominated by the e-wallet as well as debit and credit cards (Table 2). In Poland, the situation is different - comparing to global trends. Using an electronic wallet is not so often used when making payments for goods and services. Bank transfers have a very large share in making non-cash payments. Therefore, payment systems and schemes are a very important element of the financial system that can significantly affect the shape of the infrastructure of this system.

Table 2 - The distribution of non-cash payments in the world and in Poland, in\% (Developed by author based on, Global payments report, November 2017, Wordpay)

\begin{tabular}{|l|c|c|c|}
\hline & \multicolumn{2}{|c|}{ World } & Poland \\
\hline & 2016 & 2021 & 2016 \\
\hline e-Wallet & 18 & 46 & 15 \\
\hline Credit Card & 29 & 15 & 7 \\
\hline Debit Card & 13 & 8 & 15 \\
\hline Bank transfer & 17 & 16 & 46 \\
\hline Cash on delivery & 9 & 7 & 9 \\
\hline Other & 14 & 8 & 5 \\
\hline
\end{tabular}

Payment systems create a system composed of many complementary factors. Several types of risks related to the proper functioning of this financial market element are noticeable in these systems. The safety of financial institutions is inextricably linked to risk, therefore the management of financial institutions is the management of various types of risk [Capiga, 2015]. In the case of improper functioning of one of the components constituting payment systems, it can significantly affect the stability of the entire payment system - and next the functioning of financial institutions and the entire financial system. The payment system is the legal solutions between at least three institutions, at least one of the institutions must be, among others (National Bank of Poland, central bank of another country, domestic bank, credit institution, investment firm) [Act 2001].

Pursuant to the Banking Act [Act 1997], the National Polish Bank was entrusted with organizing monetary settlements and acting for the stability of the domestic financial system. System supervision is exercised over the payment system, which focuses on the functioning of payment systems, payment schemes, settlement systems and securities settlement systems, as well as providing acquiring services. The role of the National Bank of Poland in exercising supervision over the payment system is primarily focused on [Policy 2017]:

- assessing the applications of entities that intend to conduct activity in this field;

- obtaining current information from entities conducting this activity;

- undertaking actions to introduce necessary changes in the way payment systems operate.

The payment scheme is understood as a set of all rules defining how payment transactions are carried out using payment instruments (e.g. payment cards, mobile applications). The payment card system is a kind of payment scheme, however, it covers only transactions carried out with the use of payment cards, therefore there are no other forms of payment in this system. The payment system is understood as an agreement of several market participants defining common rules used to execute transfer orders.

In connection with the numerous NBP roles in the payment system, it can be said that it plays not only supervisory but also regulatory and operational role as well as acts as a catalyst for changes in this element of the financial system. The number of decisions issued by the President of the NBP regarding payment systems reflects the NBP supervision over payment systems in Poland and the dynamic development of these systems. 7 decisions were issued up to 2010 - including 5 on the National Clearing House (over 8 years of the Act on Settlement Finality in Payment and Securities Settlement Systems and on the Principles of Supervision over these Systems). Since 2010, the President of the NBP issued 19 
decisions, 13 of which concerned the National Clearing House, 4 Blue Media, and one Polish Payment Standard and First Data Poland. These decisions include among others consent to running several payment systems suggesting their dynamic development:

- BlueCash payment system,

- Clearing System for Immediate Payments,

- BLIK Mobile Payment System,

- Card Payment System.

The participants of the payment system are numerous entities (Figure 1). These entities that create the payment system are directly involved in carrying out transactions involving cash or financial instruments.

\begin{tabular}{|c|}
\hline Participants of the first level \\
\hline $\begin{array}{l}\cdot \text { hausehold } \\
\cdot \text { company }\end{array}$ \\
\hline Participants of the second level \\
\hline - payment service provides (banks, payments institutions, SKOK) \\
\hline Participants of the third level \\
\hline $\begin{array}{c}\text { - Krajowa Izba Rozliczeniowa } \\
\text { • Blue Media S.A. } \\
\text { - Polski Standard Płatności } \\
\text { - agenci rozliczeniowi }\end{array}$ \\
\hline Participants of the fourth level \\
\hline $\begin{array}{c}\cdot \text { Narodowy Bank Polski } \\
\cdot \text { Krajowy Depozyt Papierów Wartościowych S.A. }\end{array}$ \\
\hline
\end{tabular}

Institutions of the banking system infrastructure support the functioning of banks and credit organizations by setting up the circulation of information enabling the safety of financial turnover by promoting reliable and trustworthy clients and identifying clients burdened with the risk of untimely implementation of its financial obligations [Zukowski 2013].

Due to the essence of systemic supervision by the NBP over payment systems, they are divided into: systemically important payment systems, significant retail payment systems, and other retail payment systems. Among the payment systems supervised by the President of the National Bank of Poland, largevalue payment systems and retail payment systems can be distinguished [Supervision 2017]. At the end of the second half of 2017, there were 7 main payment systems in Poland [Rating 2018]:

- 2 large-value payment systems:

SORBNET2 system, maintained by the NBP;

TARGET2-NBP system, operated by the NBP in legal terms and by three central banks in operational terms (Deutsche Bundesbank, Banque de France and Banca d'Italia);

- 5 retail payment systems:

Elixir system, maintained by National Clearing House SA; 
Euro Elixir system, maintained by National Clearing House $S A$;

Express Elixir system, maintained by National Clearing House $S A$;

BlueCash system, maintained by Blue Media SA;

BLIK system, maintained by Polish Payment Standard Ltd.

The payment systems presented above are subject to systemic supervision exercised by the NBP. Nevertheless, numerous innovations in finance lead to the development of not only payment systems but also payment schemes, which are also subject to the supervision of the central bank. The payment scheme should be understood as a set of rules for carrying out payment transactions, issuing and accepting payment instruments by payment service providers and processing payment transactions made using payment instruments and payment card system [Act 2011]. Among the payment schemes, there are those being payment card systems and not being payment card systems. Among the payment schemes being payment card systems in Poland, there are four payment organizations whose payment schemes are:

- VISA Europe;

- Mastercard;

- American Express;

- Diners Club.

Financial innovations lead to dynamic development of payment schemes that are not payment card systems (Table 3).

Table 3 - Payment schemes that are not payment card systems by type of payment instrument (own study, based on NBP)

\begin{tabular}{|l|l|l|l|}
\hline \multicolumn{2}{|c|}{ Mobile application } & \multicolumn{2}{c|}{ e-wallet } \\
\hline \multicolumn{1}{|c|}{ payment organization } & \multicolumn{1}{c|}{ payment scheme } & payment organization & payment scheme \\
\hline Polski Standard Płatności Sp. z 0.o. & Schemat Płatniczy BLIK & YetiPay Sp. z o.o. & YetiPay \\
\hline mPay S.A. & mPay & SkyCash Poland S.A. & ITS Smart \\
\hline ITS Smart Sp. z o.o. & SkyCash & & \\
\hline Planet Pay Sp. z o.o. & Smoopay & & \\
\hline Bank Polska Kasa Opieki S.A. & Peopay & & \\
\hline
\end{tabular}

The level of payment systems development in Poland. Elixir is an electronic system of interbank settlements, which enables the execution of transfers in PLN. At the same time, it is not only the largest payment system in Poland, but also a system constituting the basis for the functioning of all infrastructure related to electronic banking. This system was created in 1994, it always works, and transactions are settled in three sessions a day. The development of the innovation market as well as modern distribution channels for financial services significantly affect the popularity of the Elixir system and the number of transactions made with the use of this payment system (Figure 2). For example, the number of transactions made through the Elixir system in 2017 was higher by 63\% compared to 2008.

The Euro Elixir system was launched in 2005, when it enabled Poland to execute transactions within the entire European Union. As a result of integration with the EU and the development of European payment systems, in 2008 it became part of the Single Euro Payments Area (SEPA). This step allowed for a dynamic increase in the number of transactions made using this payment system (Figure 3). In 2017, the number of transactions made using this payment system was more than seven times higher than in 2008. 


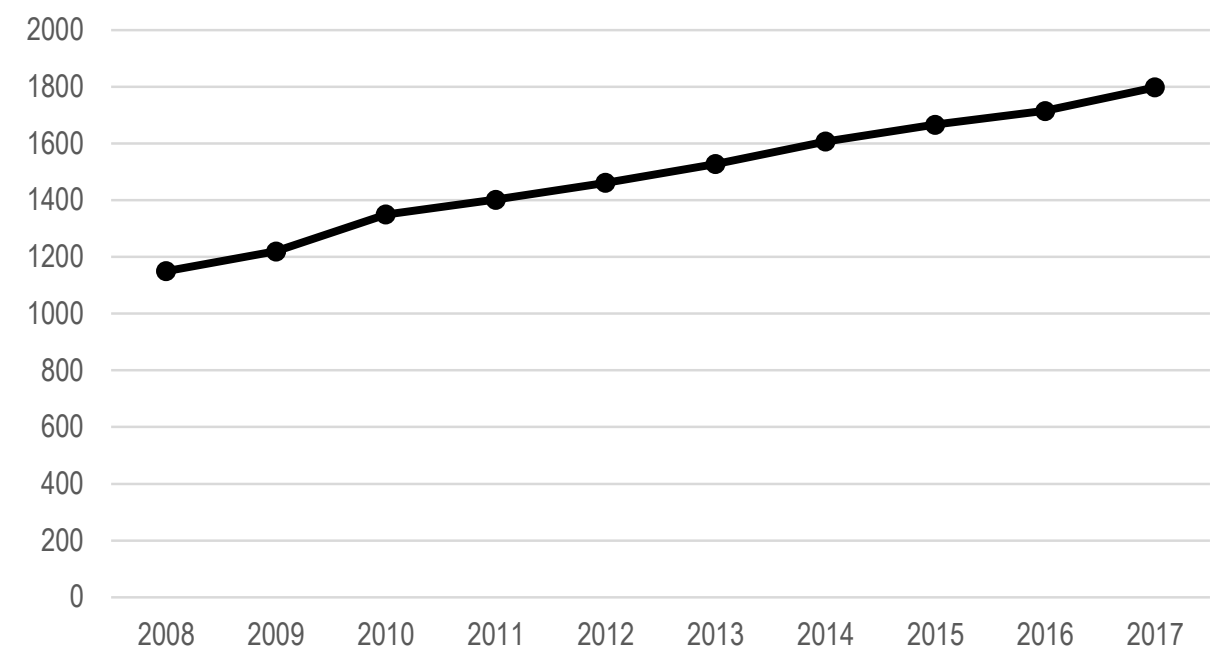

Figure 2 - Total number of transactions ELIXIR system in millions units (own study, based on NBP, KIR)

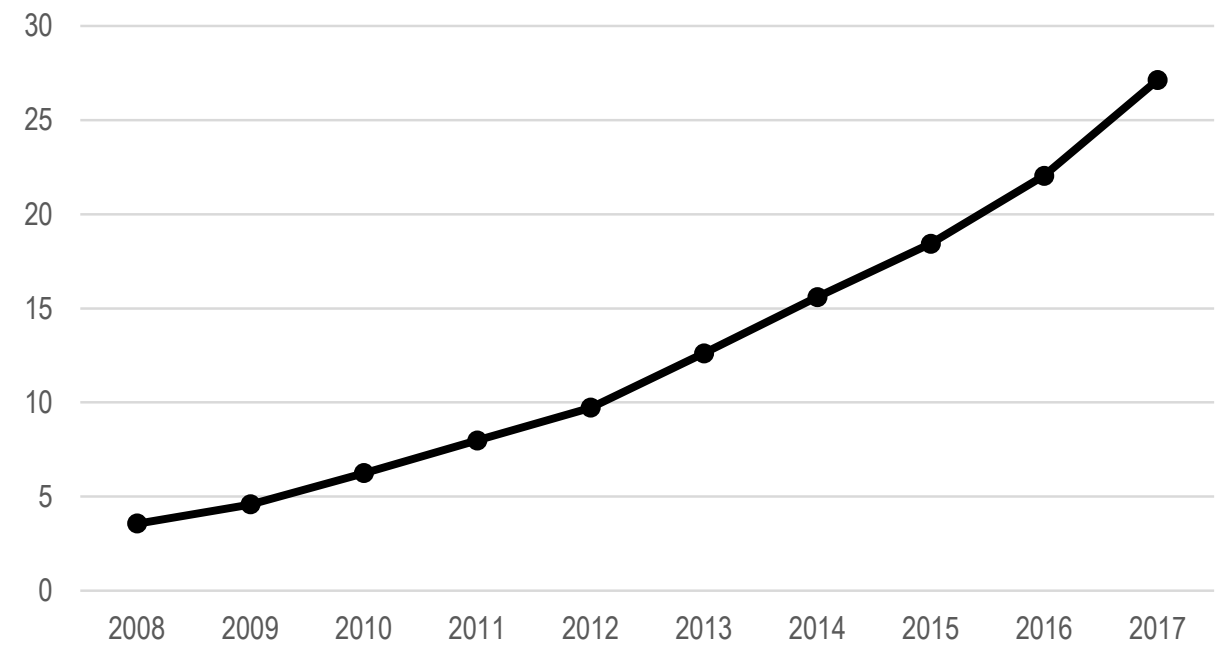

Figure 3 - Total number of transactions EURO ELIXIR system in millions units (own study, based on NBP, KIR)

The dynamic development of electronic banking supports the development of payment systems. The Express Elixir payment system was created in 2012 in Poland, enabling immediate payments. It was the second such system in Europe. In the world in 2014, immediate payment systems functioned in 14 countries. The first immediate payments system was established in the United Kingdom (Faster Payments Service (FPS)) in 2008. In 2012, such a system was also launched in Sweden, and later in Denmark. The immediate payments system operated by KIR was the first such a system in Poland. Nevertheless, the dynamic development of this market led to the fact that in 2012, the payment system BlueCash was 
launched, the operator of which is Blue Media SA. It is important to note that active participants of this system at the end of 2017 were 105 banks, of which only 6 commercial banks. The Express Elixir system cooperates with 12 banks, of which 10 are commercial banks. Figure 4 shows the level of transactions in these two immediate payments systems operating in Poland.

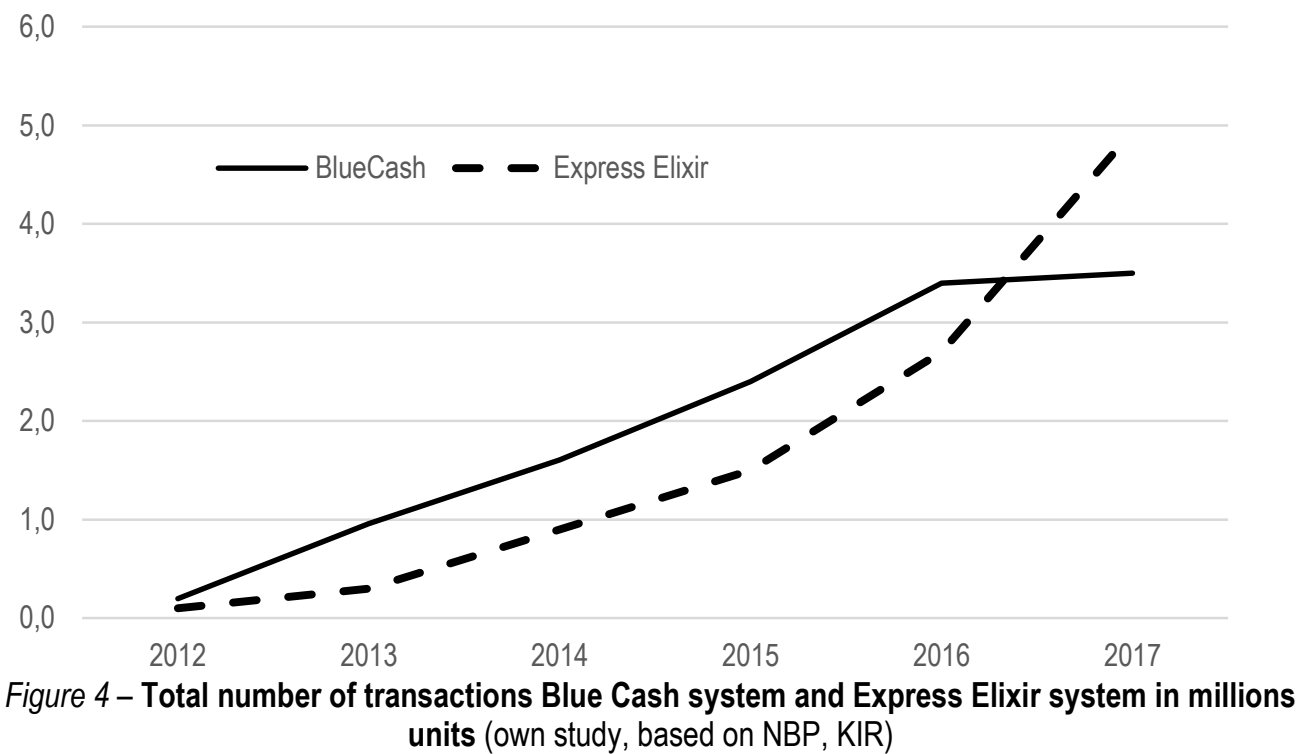

The development of innovations and preferences of the society leads to the fact that the National Clearing House as the operator of this system will implement in 2018 the possibility of making immediate transactions in euro. The development of P2P mobile payments - to the telephone number, significantly promotes the development of the Express Elixir system - despite the fact that only 5 commercial banks enabled their clients such innovative solutions at the end of 2016.

The development of knowledge and technology creates new types of uncertainty and risk, which may require a new approach to the law. Knowledge-based economy legislation can be presented in terms of the risk management system [Szpringer 2017]. Innovations on the immediate payment market can have a significant impact on the development of this type of payment market. The Bank of England decided on a revolutionary step in the functioning of payment systems in July 2017 [Bank 2017]. Its decisions led to the fact that payment institutions have access to clearing systems. This results in the fact that non-bank payment institutions have the option of setting up settlement accounts. This may result in the execution of external transfers in the near future with the use of non-bank payment institutions without the mediation of banks. It is worth noting that the Regulation of the Minister of Finance and Development of July 2017 [Regulation 2017] allows national payment organizations that are not banks to apply to the NBP for a bank account number - the clients they serve. Such activities of market regulators, as well as dynamic development of innovations - especially Fin-Tech market may lead to significant changes in the functioning of systems and payment schemes.

The Polish Payment Standard offered the BLIK payment system on the market in 2015. This system is a response to the development of innovation in this market and consumer preferences. More and more users of electronic banking - especially mobile banking lead to the dynamic development of these types of payment systems. The BLIK system allows to make payments using portable devices (mainly through 
mobile phones and tablets). The use of mobile devices in making transactions is possible in Poland from February 9, 2015 - which emphasizes the role of financial innovation in shaping payment systems and schemes. At the end of 2017, 9 banks participated in the BLIK system. Nevertheless, the scale of operation of this system is based on the use of the banking system infrastructure. That is why the BLIK covered over 232 thousand payment terminals, 255 thousand service and commercial outlets, 80 thousand online stores and nearly 17 thousand ATMs [Rating 2018]. Despite the fact that the BLIK payment system has been operating since 2015, the number of transactions performed using this payment system is growing dynamically and is already higher than the number of immediate transfers made by the BlueCash and Express Elixir payment systems (Figure 5).

\section{5}

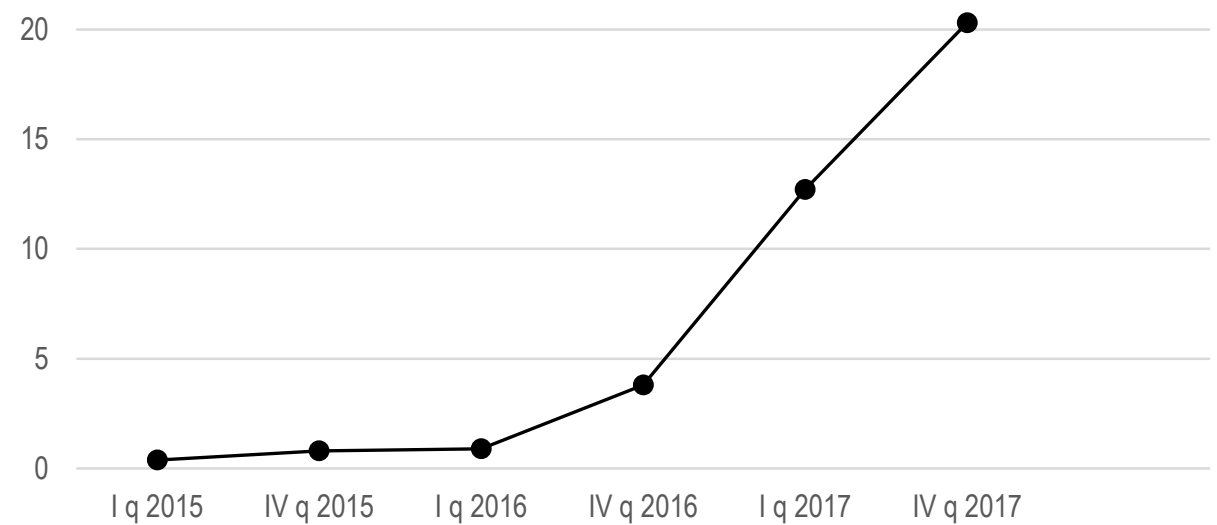

Figure 5 - Total number of transactions BLIK system in millions units (own study, based on NBP, KIR)

The development of innovations in the field of mobile banking is also conducive to the development of payment schemes (apart from the largest scale of operations - the BLIK system offered by the Polish Payment Standard Ltd.). On 13 September 2016, the Financial Supervision Authority issued to mPay SA., a license to provide payment services as a domestic payment institution [Announcement 2016]. At the end of 2016, the company offered the possibility to make payments for tickets in 16 cities in Poland, and in 17 - the possibility to make payments for parking [Report 2016].

The development of financial innovations and the liberalization of regulations in the area of the provision of payment services are conducive to the development of payment schemes that are not payment card schemes. A dynamically growing company that can significantly increase its share in this type of payment schemes is SkyCash Poland SA. It has been operating since 2009, in which it obtained the consent of the President of the NBP to operate a system of authorization and settlement of mobile payments. What is worth emphasizing already in June 2016, the company recorded over 1 million transactions per month. Of course, this result is largely influenced by parking fees (about 40\%) and the purchase of public transport tickets. It is worth noting that the company dynamically develops its other channels by offering, among others, transfers to a telephone number, cash withdrawals from ATMs and GSM top-ups, and in response to the internationalization of Polish society, it is already introducing the English version of the application, and at the turn of 2017/2018, the Ukrainian, German and Russian versions will be introduced. 
The impact of new technologies on payment systems. It is worth mentioning that the development of technology can significantly affect the employment in the banking sector. The reorganization of traditional bank branches and the creation of modern, automated banking outlets can significantly reduce the number of people employed in the banking sector. Already in 2015, EBA analysts in monitoring financial innovations (especially the FinTech sector), increased digitization of financial services. The phenomenon of automation in personal banking, without or with very limited human intervention, was considered particularly interesting [EBA, 2015].

The FinTech market development will certainly significantly:

- reduce the level of costs in financial institutions;

- create the opportunity to stand out on the market;

- make it possible to retain customers in financial institutions;

- create additional revenues for the financial sector.

According to the PWC report [Banks and Fintechs, 2017], due to the development of the FinTech market, by 2020 the largest changes will affect the individual (personal) banking sector and the form of money orders and payments (among others through the development of payment systems - enabled by the PSDII directive) (Figure 6). This entails key changes in the activities of commercial banks not only in Poland, but also around the world. These changes will lead to a redefinition of banks strategies that will be forced to change their business models-so as to be able to respond to changing consumer preferences in the use of financial services. Such tendencies are indicated, among others by EBA analysts [EBA, 2017].

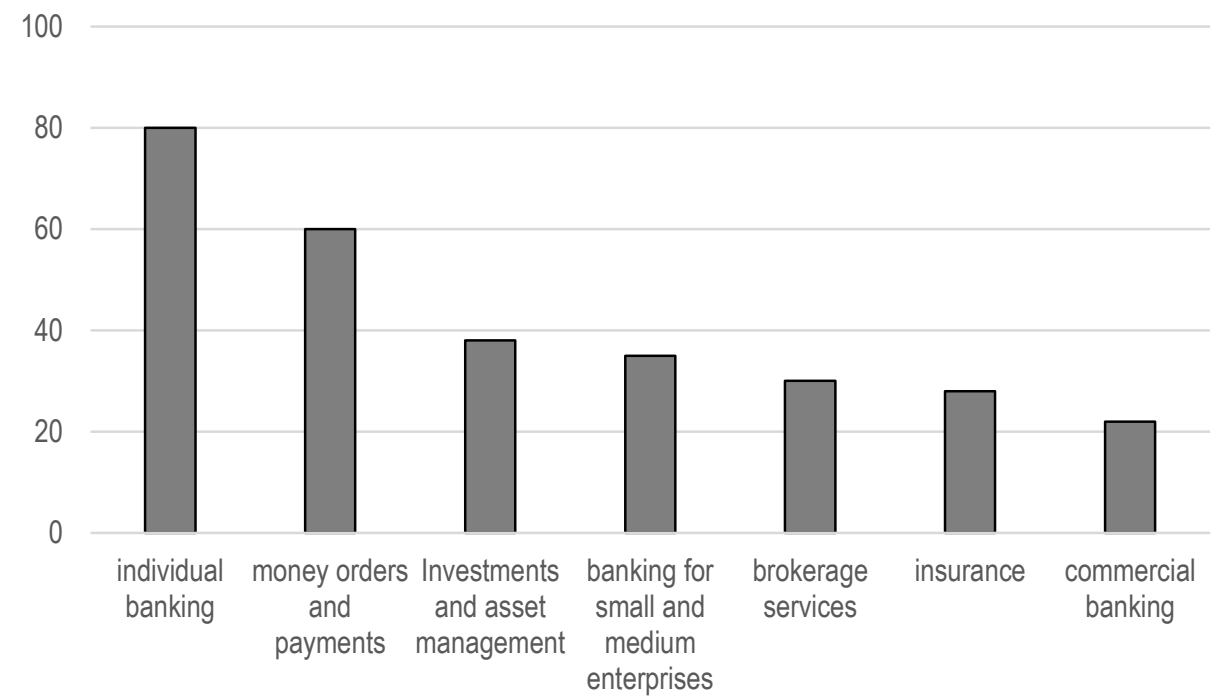

Figure 6 - The biggest changes as a result of fintech activities in the next 5 years (own study based on, Banks and Fintech, 2017, p. 18)

According to the Deloitte report [FinTech in CEE, 2016], the FinTech market in all Central European countries is valued at over EUR 2.2 billion, while the largest markets in the analysed area of Europe are:

- FinTech market in Poland - EUR 856 million;

- FinTech market in Austria - EUR 588 million; 
- FinTech market in the Czech Republic - EUR 190 million.

This may prove the strength and potential of the FinTech market in Poland, which in the opinion of experts will dynamically develop in the coming years. Financial institutions will be interested in keeping the clients they have. What is more, the strategic challenge for them is attracting innovative customers, including the so-called. Millenians who are interested in modern solutions in the field of technology used in finance.

In recent years, the symbol of innovation on the financial services market in Poland has been the dynamic development of the payment card market and their functionality. Numerous programs, such as non-cash Poland, the BLIK system and the promotion of non-cash transactions in Poland, are conducive to increasing transactions carried out without using cash. According to Visa Europe data, 2.4 contactless transactions monthly per capita are carried out in Poland. The increasing number of transactions carried out using payment cards - contactless, led to the consent of the NBP to increase the contactless payment limit without the need to enter a PIN code, up to PLN 100. It is worth noting that numerous teams are also working on increasing the security of transactions carried out, including promoting payment cards equipped with a fingerprint reader.

Despite the dynamic development of the FinTech sector in Poland, according to a report showing the latest trends in banking [Recent trends, 2017], Western European countries are definitely more developed in terms of digital transformation and the use of modern technologies.

Innovations on the immediate payments market can have a significant impact on the development of this type of market. The Bank of England decided on a revolutionary step in the functioning of payment systems in July 2017 [Bank of England, 2017]. Its decisions led to the fact that non-bank payment institutions already have the option of setting up billing accounts (such regulations are introduced by the PSD II Directive also in Poland at the end of 2018). This may result in the execution of external transfers in the near future with the use of non-bank payment institutions without the mediation of banks. It is worth noting that in Poland, the regulation of the Minister of Finance and Development of July 2017 [MFD Regulation, 2017] enables national payment organizations that are not banks to apply to the NBP for a bank account number - the clients they serve. Such activities of market regulators and dynamic development of innovations - especially FinTech market can lead to significant changes in the functioning of systems and payment schemes, and the PSDII directive implemented in EU countries can only develop this market.

Summary. The development of systems and payment schemes is inevitable. The applicable regulations and the promotion of non-cash transactions are conducive to the emergence of a larger number of enterprises that are not financial institutions. This may lead to the access of these companies to household bank accounts. This step will have a significant impact on the banking sector and the role of banks in payment systems. Households increasingly prefer electronic payments (including through mobile applications and electronic wallets). This leads to numerous changes in banks strategies, which have to in a way depart from traditional channels of access to banking services, in favour of modern technological solutions. Market regulations - especially the PSD II Directive, opens the banking market in terms of payments, creating the so-called open banking. The development of payment systems in Poland indicates a very high value of this market, while research indicates significant strategic changes in the scope of payment systems functioning.

Banki i Fintechy - Małżeństwo z rozsądku, Raport PWC, 2017.

Bank of England extends direct access to RTGS accounts to non-bank payment service providers, 19 July2017.

Capiga M., Bezpieczeństwo transakcji finansowych w Polsce, Wydawnictwo CeDeWu.pl, Warszawa, 2015.

Directive 2014/65/EU of the EUROPEAN PARLIAMENT AND OF THE COUNCIL of 15 May 2014 on markets in financial instruments and amending Directive 2002/92/EC and Directive 2011/61/EU. 
Directive 2015/2366/EU of the EUROPEAN PARLIAMENT AND OF THE COUNCIL of 25 November 2015 on payment services in the internal market, amending Direc-tives 2002/65/EC, 2009/110/EC and 2013/36/EU and Regulation (EU) No 1093/2010, and repealing Directive 2007/64/EC.

Dorfleitner G., Hornuf L., Schmitt M., Weber M., Fintech in Germany, Springer, 2017.

FinTech w Polsce, Bariery i szanse rozwoju, Raport, 2017.

FinTech in CEE, charting the course for innovation in financial services technology, Report Deloitte, 2016.

Global Payments Report, Worldpay, November 2017.

Komunikat z 320. posiedzenia Komisji Nadzoru Finansowego w dniu 13 września 2016 r.

Nadzór nad Systemem Płatniczym - Systemy płatności, NBP.

Ocena funkcjonowania polskiego systemu płatniczego II półroczu 2017 r. Narodowy Bank Polski, Departament Systemu Platniczego, Warszawa, 2018.

Polityka sprawowania przez Narodowy Bank Polski nadzoru systemowego w zakresie systemu płatniczego, Narodowy Bank Polski, Departament Systemu Płatniczego, Warszawa, czerwiec 2017

Raport roczny za rok obrotowy 2016, MPAY S.A.,

Rozporządzenie Ministra Finansów i Rozwoju, z dnia 10 lipca 2017 roku, w sprawie identyfikatorów i numerów rozliczeniowych nadawanych niektórym dostawcom usług płatniczych oraz unikatowych identyfikatorów nadawanych rachunkom płatniczym prowadzonym przez tych dostawców, Poz. 1360 .

Recent trends in banking, Report Deloitte, 2017.

Szpringer W., Nowe technologie a sektor finansowy, Wydawnictwo Poltext, Warszawa, 2017.

Sektor finansowy coraz bardziej FinTech, raport PWC, 2016

Ustawa z dnia 29 sierpnia 1997 r. Prawo Bankowe, Dz. U. z 2013 r. poz. 908, z późn. zm.

Ustawa z dnia 24 sierpnia 2001 r. o ostateczności rozrachunku w systemach płatności i systemach rozrachunku papierów wartościowych oraz zasadach nadzoru nad tymi systemami, Dz.U. $2001 \mathrm{Nr} 123$ poz. 1351.

Ustawa z dnia 19 sierpnia 2011 r. o usługach płatniczych, Dz.U. z 2016 r. poz. 1572, z późn. zm.

World FinTech Report, Capgemini, 2017.

World Payments Report, Capgemini, 2017.

World Retail Banking Report, Capgemini, 2017.

Żukowski M., Instytucje tworzące infrastrukturę systemu bankowego [w:] Bankowość, pod. Red. M. Zaleska, Wydawnictwo C.H.Beck, Warszawa, 2013.

M. Фолварски, Ph.D, Краківський університет економіки, (Краків, Польща).

Вплив регуляторних інструментів на розвиток платіжних систем в Польщі

Аналіз даних свідчить, що у світі зростає зацікавленість у розвитку інноваційних безготівкових методів здійснення платежів. На сьогодні обсяги використання електронних гаманців зрівнявлися з обсягами дебетових та кредитних карт. Тенденції розвитку даного ринку у Польщі дещо відрізняються від загальносвітових, оскільки банківські платежі займають більшу частку безготівкових трансакцій. Автор зауважує, що ігнорування банками тенденцій розвитку сектора роздрібних послуг може призвести до серйозних загроз для банків та втрати майже половини їх доходів від здійснення безготівкових розрахунків. Таким чином, оптимальною стратегією для банківських установ $є$ створення спільних Start-uр програм (інкубаторів), венчурних фондів для фінансування FinTech компаній. При цьому зазначається, що швидкий розвиток безготівкових трансакцій визначає виникнення иілого пулу нових ризиків у діяльності банків. Відповідно до законодавства Національний банк Польщі, як центральний банк повинен сформувати систему нагляду за функціонуванням платіжних систем, платіжних схем, розрахункових систем та систем розрахунків за допомогою цінних паперів, а також системою надання еквайрингових послуг. Отже розвиток небанківського сектору електронних платежів формує нові вимоги до системи регулювання та потребує ревізії наглядових ффункцій, трансформації інфрраструктури банківського сектора. Трансформація системи нагляду повинна базуватися на сприйнятті невідворотності розвитку платіжних систем та платіжних схем, розвитку інсрраструктури ринку платежів за рахунок компаній, які не $є$ фрінансовими установами $і$, відповідно, доступу иих компаній до банківських рахунків домашніх господарств.

Ключові слова: платіжна система, мобільні додатки, електронний гаманець, банк. 